\section{FABRICATION OF POLY(LACTIC-CO-GLYCOLIC ACID)/Calcium Phosphate Bone Cement Composite: SyNTHESIZATION OF CALCIUM PhOSPHATE FROM CRAB SHELLS}

Mohammad Redzuan Abdul Hanana, Ahmad Kafrawi Nasutionb, Rafaqat Hussainc, Syafiqah Saidina,d*

aFaculty of Biosciences and Medical Engineering, Universiti Teknologi Malaysia, 81310 UTM Johor Bahru, Johor, Malaysia bDept. of Mechanical Engineering, Faculty of Engineering, Muhammadiyah University of Riau, Pekanbaru, Indonesia

cDepartment of Physics, COMSATS Institute of Information Technology, Islamabad, Pakistan

dIJN-UTM Cardio Centre, Universiti Teknologi Malaysia, 81310 UTM Johor Bahru, Johor, Malaysia
Article history

Received

24 August 2017

Received in revised form

6 February 2018

Accepted

15 February 2018

Published online

3 June 2018

*Corresponding author syafiqahs@utm.my

\section{Graphical abstract}

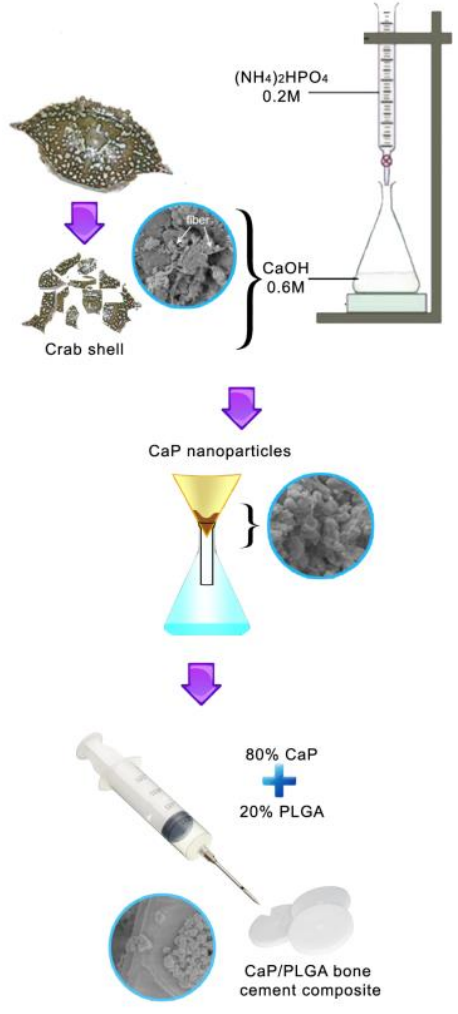

\begin{abstract}
Crab shells are waste product, rich with calcium compound. Calcium element is often used as a material for bone scaffold due to its bioactive and biodegradation properties. In this study, calcium phosphate (CaP) nanoparticles were synthesized from crab shells through a wet chemical route. The CaP nanoparticles were then sintered and mixed with poly (lactic-co-glycolic acid) (PLGA) to form a bone cement composite. The mixture was casted in a cylinder shape and it was characterized through ATR-FTIR, XRD, FESEM, contact angle and DSC analyses. The CaP pellet and the CaP/PLGA bone cement composite were then subjected to in vitro simulated body fluid (SBF) bioactivity test. The CaP/PLGA bone cement composite was found to have a composition of crystal CaP and PLGA with a tolerable glass transition state, suitable to be used in a physiological environment. The CaP nanoparticles were agglomerated on the 3D interconnected surface of PLGA. The hydrophobicity of the CaP was increased (66.94\%) with the addition of PLGA as a binder matrix where this composite has induced the formation of apatite layer. This bioactive property is crucial in fabricating a bone substitute material as it can promotes cell penetration, attachment and proliferation.
\end{abstract}

Keywords: Bone cement, calcium phosphate, poly(lactic-co-glycolic acid), crab shells, bioactive

\begin{abstract}
Abstrak
Cangkerang ketam ialah produk buangan, kaya dengan kompaun kalsium. Elemen kalsium sering digunakan sebagai bahan perencah tulang kerana sifat bioaktif dan bioterurai. Dalam kajian ini, nanopartikel kalsium fosfat (CaP) disintesis daripada cangkerang ketam melalui jalan kimia basah. Nanopartikel CaP kemudiannya dibakar dan dicampur dengan asid poli(laktik-ko-glikolik) (PLGA) untuk menghasilkan komposit simen tulang. Campuran dihasilkan dalam bentuk silinder dan ia dicirikan melalui analisis ATR-FTIR, XRD, FESEM, sudut sentuhan dan DSC. Pelet Ca/P dan komposit simen tulang CaP/PLGA kemudiannya melalui ujian bioaktif cecair simulasi badan secara in vitro. Komposit simen tulang CaP/PLGA mempunyai komposisi CaP kristal dan PLGA dengan toleransi tahap perubahan kaca, sesuai untuk digunakan
\end{abstract}


dalam persekitaran fisiologi. Nanopartikel CaP berkumpul pada permukaan tiga dimensi hubungan antara PLGA. Sifat fobia air CaP bertambah (66.94\%) dengan penambahan PLGA sebagai pengikat matrik di mana komposit ini telah menumbuhkan lapisan apatit. Sifat bioaktif ini penting dalam pembuatan bahan tulang di mana ia dapat menggalakkan penembusan, pelekatan dan pertambhan sel.

Kata kunci: Simen tulang, kalsium fosfat, asid poli(laktik-ko-glikolik), cangkerang ketam, bioaktif.

(C) 2018 Penerbit UTM Press. All rights reserved

\subsection{INTRODUCTION}

Crab is classified as crustacean group which has a thick exoskeleton shell [1]. This creature lives in seawater, freshwater and partly on land [1]. Portunus pelagicus or also called "flower crab" in East Asian countries [2], is commonly available at seafood markets and restaurants to be served as one of the main seafood dishes [3]. Crab shell is a waste product as it cannot be eaten and does not give advantage to its collector. Thus, it is abundantly accessible and available without any specific use.

Crab shell is one of the natural resources, rich with calcium carbonate $\left(\mathrm{CaCO}_{3}\right)$ [4]. Extraction of $\mathrm{CaCO}_{3}$ from natural resources is beneficial as an alternative option to synthesize bioceramic material [5]. Bioceramic material derived from natural resources could provide better metabolic activity and active response of physiological environment compared to a synthetic CaP [6]. Several CaP derivatives such as hydroxyapatite (HAp, $\left.\mathrm{Ca}_{10}\left(\mathrm{PO}_{4}\right)_{6}(\mathrm{OH})_{2}\right)$, biphasic calcium phosphate (BCP) and tricalcium phosphate (TCP, $\left.\mathrm{Ca}_{3}\left(\mathrm{PO}_{4}\right)_{2}\right)$ which obtained from natural resources, are actively being used in dentistry and orthopedic applications [5, 7-8] as well as in bone reconstructive surgery [9] .

Calcium phosphates are also being utilized as synthetic bone graft substitutes [10] and being incorporated in a bone implant coating [11] due to its biocompatible, bioactive, biodegradable and osteoconductive properties. The emergence of CaP from natural resources that has similar structure and morphology with human bones [12] provides benefit in the treatment of bone disease and for regeneration of damaged organs and tissues. Besides, CaP can be produced in large quantities at relatively low cost [5]. The synthesization of CaP from waste product will further cut the cost of CaP production.

From the last four decades, several efforts have been conducted in developing CaP bone cement including the study on various size of CaP granules to cover the size of bone defect [13]. Furthermore, the viscosity of injectable CaP bone cement has also been optimized to tolerate the grafting and filling of missing bone [14-16], either in the form of cement or paste by adjusting the wettability property of the materials [17-19]. Another strategy to enhance the property of CaP bone cement is, by incorporating a degradable polymer such as poly(lactic-co-glycolic acid) (PLGA), polylactic acid (PLA) and polyetherketoneketone (PEKK) which acts as a binder to the cement [20].

Therefore, the aim of this study was to synthesize CaP from crab shells and to incorporate the synthesized CaP into PLGA to construct a bone cement composite. The samples were characterized through several characterization analyses including attenuated total reflectance-Fourier transform infrared spectroscopy (ATR-FTIR), X-ray diffractometer (XRD), field emission scanning electron microscopy (FESEM), wettability and differential scanning calorimetry (DSC) analyses. Finally, the bioactivity of the CaP and the CaP/PLGA bone cement composite were investigated through in vitro simulated body fluid (SBF) bioactivity test by visualizing the formation of apatite layer under SEM.

\subsection{METHODOLOGY}

\subsection{Sample Preparation}

Crab (Portunus pelagicus) shells were collected from local seafood restaurants in the area of Johor Bahru, Johor, Malaysia. The shells were cleaned and washed to remove macro residues. They were crushed into small pieces using mortar and pestle, treated in an ultrasonic bath (LIR Biotech ${ }^{\mathrm{TM}}$, Malaysia) for 15 minutes at room temperature to remove micro residues and dried in an oven (UN30, Memmert Gmbh, Germany), overnight. The treated shells were then immersed in $1.0 \mathrm{M} \mathrm{NaOH}$ at $80^{\circ} \mathrm{C}$ for 1 hour under stirring condition to denature the protein and to deacetylation the chitin and chitosan [7]. The shells were rinsed twice with deionized water and dried in an oven (UN30, Memmert Gmbh, Germany) for 6 hours at $110^{\circ} \mathrm{C}$ [12]. It was denoted as $\mathrm{CaCO}_{3}$ powders. The $\mathrm{CaCO}_{3}$ powders were then calcined at $1000^{\circ} \mathrm{C}$ in a muffle furnace (BSK-1700-X-S, MTI Corp, USA) for 5 hours to form $\mathrm{CaO}$ [12] and further crushed with mortar and pestle into a powder form.

The procedures to synthesize CaP nanoparticles were conducted according to Unabia et al. [21] with 
slight modification. The $\mathrm{CaO}$ powders were dissolved in distilled water at $40^{\circ} \mathrm{C}$ under stirring condition to form calcium hydroxide $(\mathrm{CaOH})$. A total of $100 \mathrm{~mL}$ of $0.2 \mathrm{M}$ diammonium phosphate $\left(\left(\mathrm{NH}_{4}\right)_{2} \mathrm{HPO}_{4}\right)$ was titrated into $100 \mathrm{~mL}$ of $0.6 \mathrm{M} \mathrm{CaOH}$ where the titration parameters were set at $40^{\circ} \mathrm{C}$ and $\mathrm{pH} 9$, under stirring condition. The CaP mixture was then continuously stirred at $40^{\circ} \mathrm{C}$ for another 4 hours. The homogenized CaP mixture was leaved at room temperature for 24 hours to allow a complete reaction and precipitation. The filtration of CaP was done using a filter paper, followed by a drying process at $110^{\circ} \mathrm{C}$ for 5 hours and sintering process in a muffle furnace (BSK-1700-X-S, MTI Corp, USA) at $1000^{\circ} \mathrm{C}$ for 4 hours.

Finally, a bone cement composite was prepared with a composition of 20 wt\% PLGA and 80 wt\% CaP. A total of $0.2 \mathrm{~g}$ of PLGA was dissolved in $0.5 \mathrm{~mL}$ of dimethyl sulfoxide (DMSO). The PLGA solution was then added into $0.8 \mathrm{~g}$ of CaP nanoparticles under vigorous agitation. Finally, the CaP/PLGA mixture was injected, molded and left to solidify at room temperature.

\subsection{Surface Characterization}

The ATR-FTIR (Nicolet iS5-IR Spectrometer, Thermo Scientific, USA) was used to verify the chemical composition of the samples at a frequency interval between $500 \mathrm{~cm}^{-1}$ and $1000 \mathrm{~cm}^{-1}$. The number of scanning and resolution of 36 and 4 were used, respectively, to analyze the samples. The chemical composition of the samples was further clarified by XRD instrument (D5000, Siemens, Germany). The analysis was performed at $40 \mathrm{kV}$ and $40 \mathrm{~mA}$ to recognize the crystallographic phases of the samples and the size of crystal particles. The data were recorded in $2 \theta$ range from $5^{\circ}$ to $60^{\circ}$ using CuKa radiation of $1.5406 \AA$.

The structural morphology of the samples was examined by FESEM (SU8020, HITACHI, Japan) at 5000x, 10000x and 30000x magnifications. Each sample was sputter coated with an ultrathin platinum film (Q150R, Quorum Technologies, England) for better image visualization. The FESEM images were then subjected to a mapping analysis using Image J software (NIH, MD, USA) to determine the particle size.

For the water contact angle measurement, a pellet compressor (E-Z Press, International Crystal Laboratories, USA) was used to compress $1.0 \mathrm{~g}$ of CaP powders into a pellet form (diameter $=1.4 \mathrm{~cm}$; thickness $=0.3 \mathrm{~cm}$ ). The compression was run for 60 seconds at 1000 Psi. While, a sample of CaP/PLGA bone cement composite with a diameter of $1.4 \mathrm{~cm}$ and a thickness of $0.3 \mathrm{~cm}$ was also prepared for the same purpose. The surface wettability of the samples was then investigated by using a video contact angle instrument (VCA, Optima, AST products, Inc., USA) by dropping $0.5 \mathrm{~mL}$ deionized water on the sample surfaces. The angle of water drop was recorded within 2 seconds at three difference spots to obtain an average value.

\subsection{Thermal Characterization}

The thermal characteristic of the CaP/PLGA bone cement composite was analyzed using DSC (DSC 2000, Perkin Elmer, US) to determine the transition glass temperature, Tg, of the bone cement composite. A heat/cool/reheat method was used to remove the thermal history. The heating temperature was set between $24^{\circ} \mathrm{C}$ and $180^{\circ} \mathrm{C}$ with a rate of $5^{\circ} \mathrm{C} / \mathrm{min}$ under nitrogen atmosphere. The reference pan with a cover was let empty during the scanning process.

\subsection{In Vitro SBF Bioactivity Test}

The bioactivity of the CaP/PLGA bone cement composite and the CaP pellet was identified through in vitro simulated body fluid (SBF) bioactivity test to simulate an apatite formation. The preparation of SBF solution was referred based on the work of Kokubo and Takadama [22]. The CaP/PLGA bone cement composite and the CaP pellet were immersed in the SBF solution at $\mathrm{pH} 7.4$ for 1,3 and 7 days by maintaining the environment temperature at $36.5^{\circ} \mathrm{C}$ in an ambient shaker incubator (SI-50D, Protech ${ }^{\circledR}$, Malaysia). The SBF solution was refreshed every 24 hours to provide adequate ions for apatite nucleation. The samples were collected following the time-points, dried and coated with a thin gold film using a gold sputter coater (EM CPD300, LEICA, Germany) for the visualization under SEM (SEM TM3000, HITACHI, Japan). The images were captured at $100 \times, 500 \times$ and $1000 \times$ magnifications.

\subsection{RESULTS AND DISCUSSION}

Calcium phosphate is biologically active to enhance osseointegration. It has been used in the fabrication of clinical total hip implants for cell survivability [23], to overcome the loosening of pin resident of an external fixator [24], to allow earlier weight bearing after tibial plateau fractures [25], etc. In this study, the CaP nanoparticles were synthesized through a chemical route by utilizing the extraction of $\mathrm{CaCO}_{3}$ from crab shells. Most CaPs are demonstrating burst degradation. Therefore, this property was improved through the incorporation of PLGA polymer. Figure 1 shows the ATR-FTIR spectra of pre-treated crab shells, $\mathrm{CaCO}_{3}, \mathrm{CaO}, \mathrm{CaP}$ and CaP/PLGA bone cement composite. The pre-treated crab shells demonstrated the existence of several peaks of primary amine at $1400-1640 \mathrm{~cm}^{-1}$. The process to produce $\mathrm{CaCO}_{3}$ has removed one the amine peaks at $1640 \mathrm{~cm}^{-1}$, signifying the detachment of some proteins from the shells. The $\mathrm{CO}_{3}{ }^{2-}$ peaks were clearly visible at 711 and $870 \mathrm{~cm}^{-1}$ in the $\mathrm{CaCO}_{3}$ spectrum, presenting the component of carbonate in the powders [26]. While, high intensity peak of crystal $\mathrm{OH}^{-}$in the $\mathrm{CaO}$ spectrum showed the calcification of hydroxyl compound after the sintering process. 


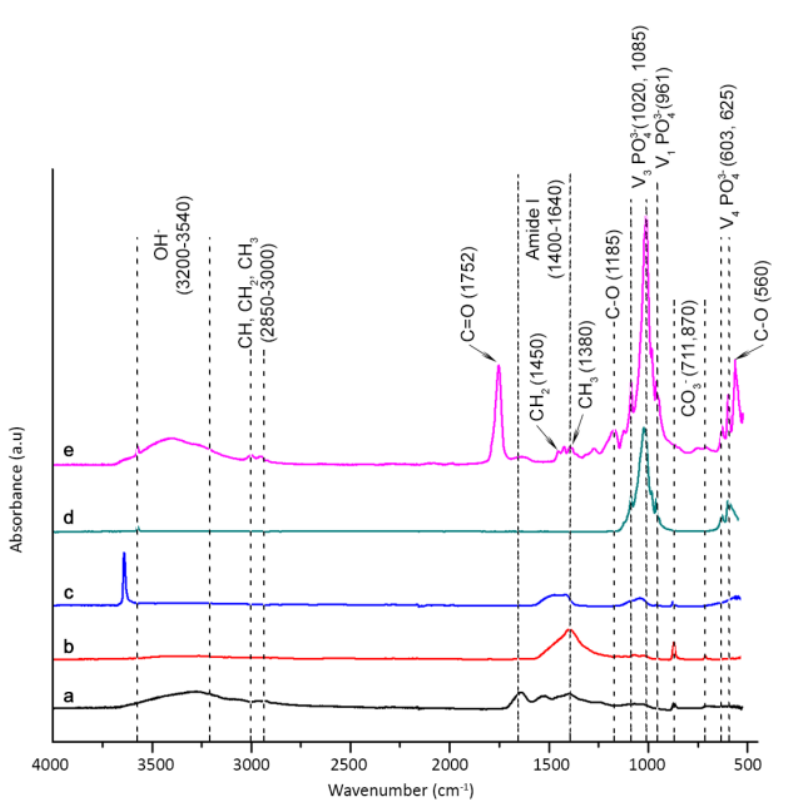

Figure 1 ATR-FTIR spectra of a) pre-treated crab shells b) $\mathrm{CaCO}_{3}$ c) $\mathrm{CaO}$ d) $\mathrm{CaP}$ and e) CaP/PLGA bone cement composite

The synthesization of CaP led to the removal of amine groups and to the appearance of phosphate peaks, $\mathrm{V}_{1} \mathrm{PO}_{4^{3-}}\left(961 \mathrm{~cm}^{-1}\right), \mathrm{V}_{3} \mathrm{PO}_{4}{ }^{3-}\left(1010 \mathrm{~cm}^{-1}\right.$ and $\left.1085 \mathrm{~cm}^{-1}\right)$ and $V_{4} P^{3-}\left(603 \mathrm{~cm}^{-1}\right.$ and $\left.625 \mathrm{~cm}^{-1}\right)$. Those peaks were accessible in the CaP powders and the CaP/PLGA bone cement composite. The sharp peaks of $\mathrm{V}_{3} \mathrm{PO}_{4}{ }^{3-}$ at $1010 \mathrm{~cm}^{-1}$ and $1085 \mathrm{~cm}^{-1}$ were pre-identified as TTCP and $\beta-T C P$, respectively [27]. While, the $\mathrm{V}_{1} \mathrm{PO}_{4}{ }^{3-}$ and the $\mathrm{V}_{4} \mathrm{PO}_{4} 4^{-3}$ peaks resembled HA formation [27]. Those CaP compounds were further clarified by the XRD analyses. The incorporation of PLGA inside the bone cement composite also led to the detection of several PLGA functional groups including $\mathrm{CH}, \mathrm{CH}_{2}, \mathrm{CH}_{3}$ stretching vibrations in between of 2850 and $3000 \mathrm{~cm}^{-1}$ [28]. Besides, weak peaks of $\mathrm{CH}_{2}$ and $\mathrm{CH}_{3}$ were observed at $1450 \mathrm{~cm}^{-1}$ and $1380 \mathrm{~cm}^{-1}$, respectively. Another two peaks at $560 \mathrm{~cm}^{-1}$ and $1185 \mathrm{~cm}^{-1}$ representing the $\mathrm{C}-\mathrm{O}$ functional groups and one peak at 1750 $\mathrm{cm}^{-1}$ representing the carbonyl $\mathrm{C}=\mathrm{O}$ functional group were also noticed in the spectra [29].

The XRD pattern in Figure 2 shows the mapping of HA and B-TCP following the Joint Committee on Powder Diffraction Standards (JCPDS) datasheets (HA: JCPDS 09-0432 and B-TCP: JCPDS 09-0169). Three main peaks of HA were found at $31.75^{\circ}, 32.10^{\circ}$ and $32.85^{\circ}$ with the crystal lattice of (211), (112) and (300). While three main peaks of $\beta$-TCP were noticed at $25.90^{\circ}, 28.00^{\circ}$ and $31.25^{\circ}$ with the crystal lattice of (1010), (214) and (0210). The crystallite size of the CaP powders was calculated to be $55.06 \mathrm{~nm}$ using Scherrer formula. The PLGA in the bone cement composite was not identified in the XRD pattern due to its non-crystallize property.

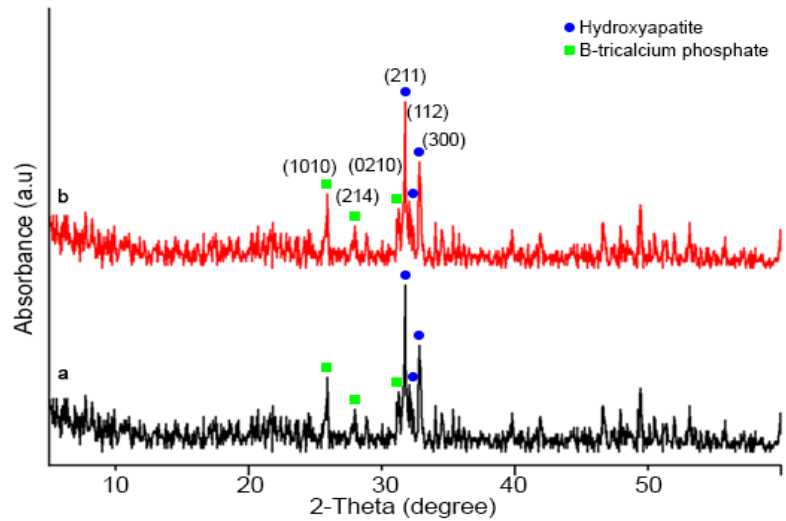

Figure 2 XRD spectra of a) CaP and b) CaP/PLGA bone cement composite

A 3D interconnected macro-porous structure of $\mathrm{CaP}$ is an ideal and essential structure for bone graft material [30]. A porous design is able to enhance mechanical interconnection between implanted scaffolds and adjacent tissues, thus providing better mechanical stability [31]. Figure 3 displays the morphology of pre-treated crab shell, $\mathrm{CaCO}_{3}, \mathrm{CaO}$, $\mathrm{CaP}$ and CaP/PLGA bone cement composite. A fiber-like shape was visible on the crab shell powders that hold the particles. After the $\mathrm{NaOH}$ treatment, the $\mathrm{CaCO}_{3}$ powders demonstrated no fiber-like shape as the treatment process denatured most proteins that attached on the crab shells. This result was supported by the FTIR analysis in Figure 1 where the amine peak at $1640 \mathrm{~cm}^{-1}$ was disappeared from the $\mathrm{CaCO}_{3}$ spectrum.
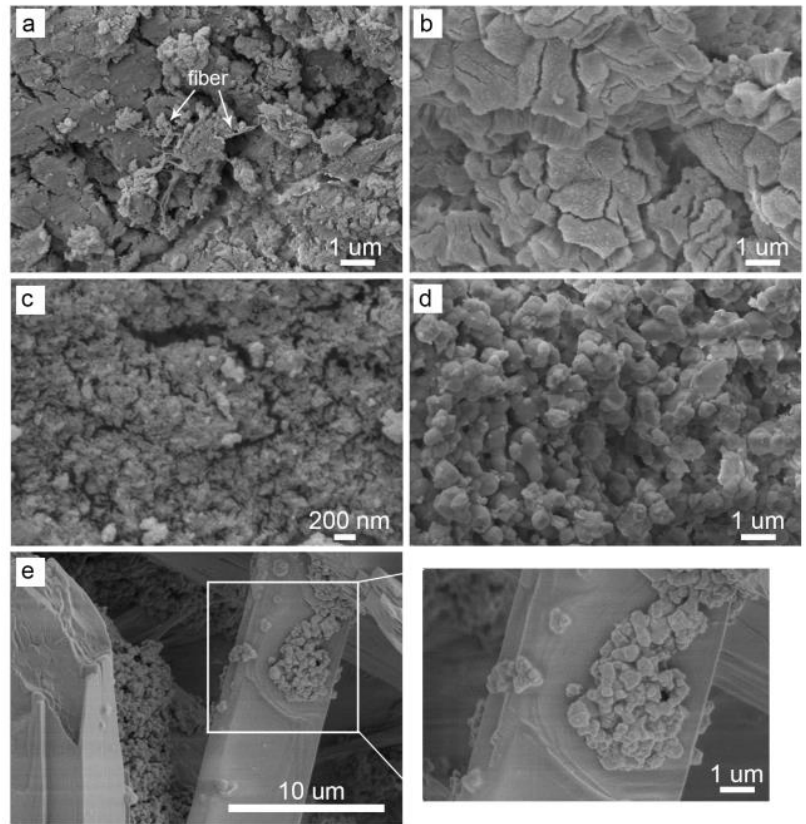

Figure 3 Surface morphologies of a) crab shells b) $\mathrm{CaCO}_{3} \mathrm{c}$ ) $\mathrm{CaO}$ d) CaP and e) CaP/PLGA bone cement composite 
The sintering process that transformed the $\mathrm{CaCO}_{3}$ into the $\mathrm{CaO}$ has shrunk the $\mathrm{CaO}$ powders to be finer nanoparticles with an average diameter of $40.51 \pm 15.28 \mathrm{~nm}$. While in Figure $3(\mathrm{~d})$, the CaP nanoparticles were obtained with an average size of $298.99 \pm 123.05 \mathrm{~nm}$. However, this range of size was bigger than the calculated value in the XRD analysis due to the gold sputtering process that united some of the CaP nanoparticles, cause the visualization of bigger compound with formation of tiny bridge between the nanoparticles. An interconnection of elongated rods-like shape of PLGA with an agglomeration of CaP nanoparticles was then noticed on the CaP/PLGA bone cement composite (Figure $3(e)$ and (f)). This structure is beneficial for the degradation of bone cement that allowing cell penetration and attachment.

The wettability measurement on the CaP pellet showed a classifying of hydrophilicity property $\left(16.63 \pm 3.00^{\circ}\right)$. The hydrophobicity of the CaP was increased to $50.30 \pm 4.78^{\circ}$ after the incorporation of PLGA into the CaP to produce the CaP/PLGA bone cement composite. The increment in hydrophobicity property is important to control the degradation of $\mathrm{CaP} / \mathrm{PLGA}$ bone cement composite by restricting the penetration of water through the bone cement composite.

The glass transition, $\mathrm{T}_{\mathrm{g}}$ of the CaP/PLGA bone cement composite was measured above the physiological temperature as shown in Figure 4. The quantization of $\mathrm{T}_{\mathrm{g}}$ is needed to ensure the $\mathrm{T}_{\mathrm{g}}$ of PLGA is not shifted to a temperature lower than the temperature of human body. The CaP/PLGA bone cement composite which composed of PLGA, was soft and viscoelastic [32]. This property was steeply transformed into a glassy state when the temperature reached $45.15^{\circ} \mathrm{C}$. The bone cement composite was then gradually become harder until it reached the $\mathrm{T}_{g}$ peak of $103.38^{\circ} \mathrm{C}$. Heat treatment more than the Tg peak, drastically caused the bone cement composite to melt into a liquid phase.

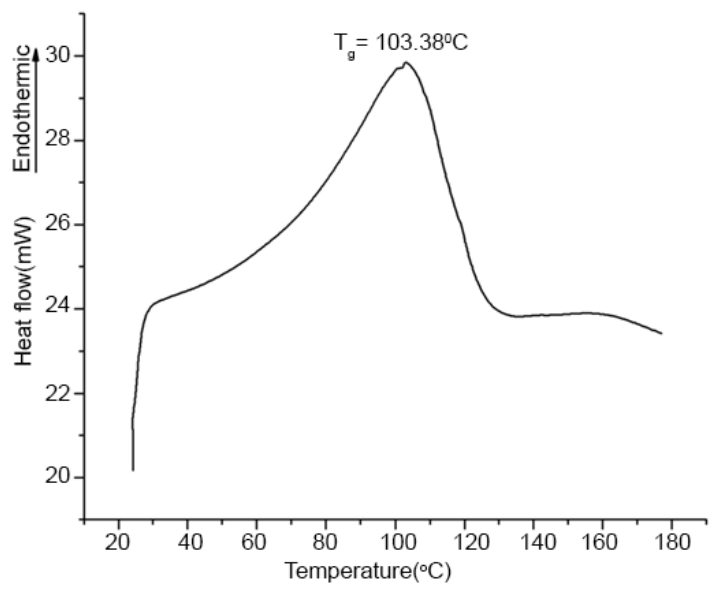

Figure 4 Glass transition, Tg, graph of CaP/PLGA bone cement composite
In spite of the physico-chemical properties, the prerequisite analysis of in vitro SBF bioactivity test is necessary to predict cells attachment and bone generation after the grafting and restoration surgery. Figure 5 shows the morphology of apatite formation on CaP pellet and CaP/PLGA bone cement composite at day 1, 3 and 7 of incubation. Within 7 days of incubation, abundant uniform apatite agglomeration were formed on the surfaces of CaP and CaP/PLGA bone cement composite, clearly visible at $1000 \times$ magnification.

A spider web-like apatite (Figure 5(b, d, f, and h)) was observed on the CaP/PLGA bone cement composite. The degradation of the PLGA from the bone cement composite produced the formation of micro-pores that allowed the penetration of SBF ions through the pores for the nucleation of apatite. In a physiological environment, the pores will be useful for water and minerals intake, in need for cell attachment and nourishment [30]. At day 7, thicker apatite layer was formed on the CaP/PLGA bone cement composite as the apatite covered the hole of the micro-pores (Figure 5(f and h)). In comparison with the apatite formation on the CaP pellet, there was no appearance of micro-pores on the CaP surfaces due to non-incorporation of PLGA.
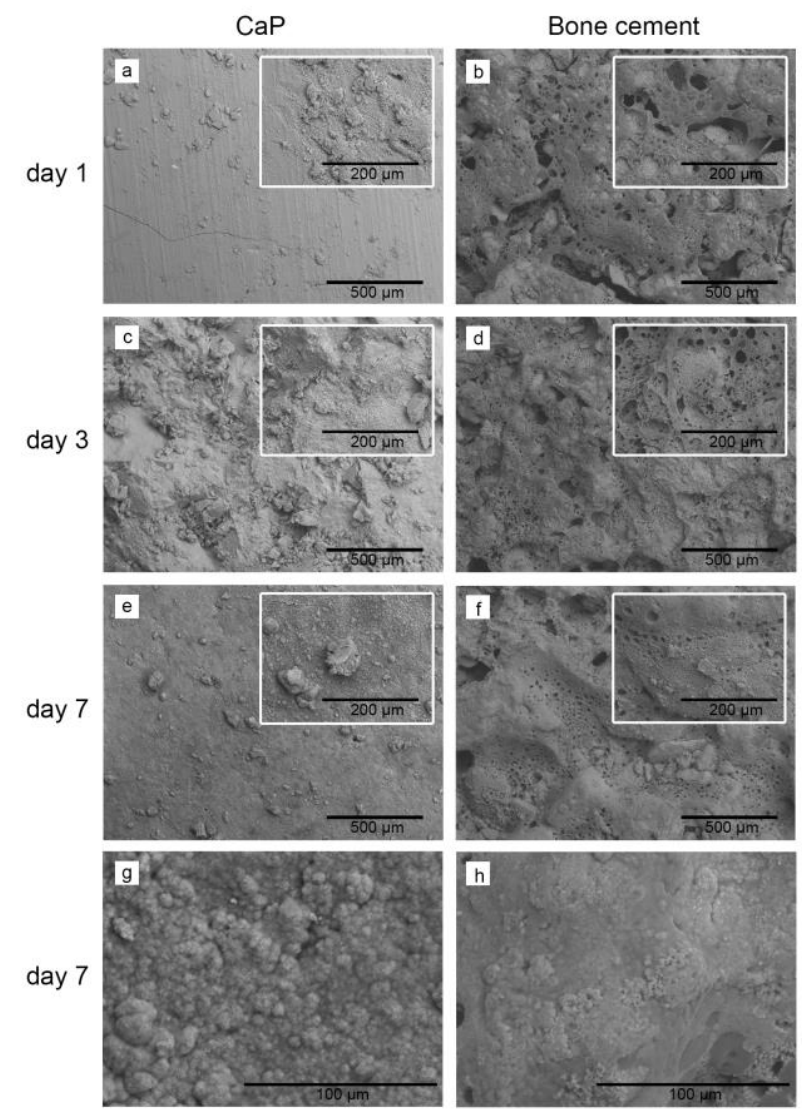

Figure 5 SEM images of apatite layer on CaP pellet and CaP/PLGA bone cement composite after in vitro SBF bioactivity test at day 1 ( $a$ and b), day 3 ( $c$ and d) and day 7 (e, f, g and h) 


\subsection{CONCLUSION}

The recycling and reusable of crab shells to be used in the synthesization of CaP is one of the practical approaches to overcome the problem of seafood waste management. The CaP derived from crab shells has a bioactive property which is beneficial for bone cement formulation. The incorporation of PLGA into the CaP nanoparticles has displayed a morphology of 3D interconnected rod-like-structure with an agglomeration of $\mathrm{CaP}$ nanoparticles. It has also increased the hydrophobicity of the bone cement composite with a tolerate apatite formation.

\section{Acknowledgement}

The authors would like to declare that there is no conflict of interest and no ethical approval is required. This study was funded by Malaysian Ministry of Higher Education through Research University Grant (RUG) Tier 2 [Q.J130000.2645.11 J68].

\section{References}

[1] Asphama, A. I., Amir, F., Malina, A. C., and Fujaya, Y. 2015 Habitat Preferences of Blue Swimming Crab (Portunus Pelagicus) Species Complex. Aquacultura Indonesiana. 16: 10-15.

[2] Ikhwanuddin, M., Liyana, A. N., Azra, M. N., Bachok, Z., and Abol-Munafi, A. B. 2014. Natural Diet of Blue Swimming Crab, portunus pelagicus at Strait of Tebrau, Johor, Malaysia. Sains Malaysiana. 43: 37-44.

[3] Talpur, A. D., Memon, A. J., Khan, M. I., Ikhwanuddin, M. Danish Daniel, M. M., and Abol-Munafi, A. B. 2011 . A Novel of Gut Pathogenic Bacteria of Blue Swimming Crab Portunus pelagicus (Linneaus, 1758) and Pathogenicity of Vibrio harveyi a Transmission Agent In Larval Culture Under Hatchery Conditions. Res J Appl Sci. 6: 116-127.

[4] Xu, Y., Gallert, C., and Winter, J. 2008. Chitin Purification from Shrimp Wastes by Microbial Deproteination and Decalcification. Appl Microbiol Biotechnol. 79: 687-697.

[5] Habraken, W., Habibovic, P., Epple, M., and Bohner, M. 2016. Calcium Phosphates in Biomedical Applications: Materials for the Future? Mater Today. 19: 69-87.

[6] Boutinguiza, M., Pou, J., Comesaña, R., Lusquiños, F., de Carlos A., and León, B. 2012. Biological Hydroxyapatite Obtained from Fish Bones. Mater Sci Eng C. 32: 478-486.

[7] Ge, H., Zhao, B., Lai, Y., Hu, X., Zhang, D., and Hu, K. 2010. From Crabshell to Chitosan-Hydroxyapatite Composite Material via a Biomorphic Mineralization Synthesis Method. J Mater Sci Mater Med. 21: 1781-1787.

[8] Metz, J. R., de Vrieze, E., Lock E-J, Schulten, I. E., and Flik G. 2012. Elasmoid Scales of Fishes as Model in Biomedical Bone Research. J Appl Ichthyol. 28: 382-387.

[9] Amer Nordin, J., Prajitno, D. H., Saidin, S., Nur, H., and Hermawan, H. 2015. Structure-property Relationships of Iron-Hydroxyapatite Ceramic Matrix Nanocomposite Fabricated Using Mechanosynthesis Method. Mater Sci Eng C. 51: 294-299.

[10] LeGeros, R. Z. 2002. Properties of Osteoconductive Biomaterials: Calcium Phosphates. Clin Orthop Relat Res. 395: 81-98.

[11] Surmenev, R. A., Surmeneva, M. A., and Ivanova, A. A. 2014. Significance of Calcium Phosphate Coatings for the Enhancement of New Bone Osteogenesis - A Review. Acta Biomater. 10: 557-579.
[12] Akram, M., Ahmed, R., Shakir, I., Wan Ibrahim, W. I., and Hussain, R. 2014. Extracting Hydroxyapatite and Its Precursors from Natural Resources. J Mater Sci. 49: 14611475.

[13] Tadic, D., and Epple, M. 2004. A Thorough Physicochemical Characterisation of 14 Calcium Phosphate-based Bone Substitution Materials In Comparison to Natural Bone. Biomater. 25: 987-994.

[14] Andrianjatovo, H., and Lemaitre, J. M. 1995. Effects of Polysaccharides on the Cement Properties in the Monocalcium Phosphate/B-Tricalcium Phosphate System. Innovation et technologie en biologie et médecine. 16: 140-147.

[15] Apelt, D., Theiss, F., El-Warrak, A. O., Zlinszky, K., BettschartWolfisberger, R., Bohner, M., Matter, S., Auer, J. A., and Von Rechenberg, B. 2004. In Vivo Behavior of Three Different Injectable Hydraulic Calcium Phosphate Cements. Biomater. 25: 1439-1451.

[16] Bohner, M. 2010. Design of Ceramic-based Cements and Putties for Bone Graft Substitution. Eur Cell Mater. 20: 1-12.

[17] Takagi, S., Chow, L. C., Hirayama, S., and Sugawara, A. 2003. Premixed Calcium-phosphate Cement Pastes. J Biomed Mater Res B Appl Biomater. 67B: 689-696.

[18] Aberg, J., Brisby, H., Henriksson, H. B., Lindahl, A., Thomsen, P., and Engqvist, H. 2010. Premixed acidic calcium phosphate cement: Characterization of strength and microstructure. J Biomed Mater Res B Appl Biomater. 93B: 436-441.

[19] Heinemann, S., Rössler, S., Lemm, M., Ruhnow, M., and Nies, B. 2013. Properties of Injectable Ready-to-Use Calcium Phosphate Cement Based on Water-Immiscible liquid. Acta Biomater. 9: 6199-6207.

[20] Wagoner Johnson, A. J., and Herschler, B. A. 2011. A Review of the Mechanical Behavior of CaP and CaP/polymer Composites for Applications in Bone Replacement and Repair. Acta Biomater. 7: 16-30.

[21] Unabia, R., Piagola, J. C., Guerrero, J. R., Vequizo, R., Gambe, J., Odarve, M. K., and Sambo, B. R. 2015. Synthesis and Characterization of Nanocrystalline Hydroxyapatite and Biphasic Calcum Phosphate using $\mathrm{Ca}(\mathrm{OH})_{2}$ and $\left(\mathrm{NH}_{4}\right) \mathrm{H}_{2} \mathrm{PO}_{4}$. Phys Status Solidi C. 12: 572-575.

[22] Kokubo, T., and Takadama, H. 2006. How Useful is SBF in Predicting in Vivo Bone Bioactivity? Biomater. 27: 29072915.

[23] Havelin, L. I., Engesaeter, L. B., Espehaug, B., Furnes, O., Lie, S. A., and Vollset, S. E. 2000. The Norwegian Arthroplasty Register: 11 years and 73,000 Arthroplasties. Acta Orthop Scand. 71: 337-353.

[24] Moroni, A., Faldini, C., Rocca, M., Stea, S., and Giannini, S. 2002. Improvement of the Bone-screw Interface Strength with Hydroxyapatite-Coated and Titanium-Coated AO/ASIF Cortical Screws. J Orthop Trauma. 16: 257-263.

[25] Russell, T. A., and Leighton, R. K. 2008. Alpha-BSM Tibial Plateau Fracture Study Group, Comparison of Autogenous Bone Graft and Endothermic Calcium Phosphate Cement for Defect Augmentation in Tibial Plateau Fractures, A Multicenter, Prospective, Randomized Study. J Bone Joint Surg. 90: 2057-2061.

[26] Reig, F. B., Gimeno Adelantado, J. V., and Moya Moreno, M. C. M. 2002. FTIR Quantitative Analysis of Calcium Carbonate (Calcite) and Silica (Quartz) Mixtures Using the Constant Ratio Method. Application to Geological Samples. Talanta. 58: 811-821.

[27] Ducheyne, P., Healy, K., Hutmacher, D. E., Grainger, D. W., and James Kirkpatrick, C. 2011. Comprehensive Biomaterials. 1st ed. Amsterdam: Elsevier. 1: 1-705.

[28] Marques, D. R., dos Santos, L. A., Schopf, L. F., and de Fraga, J. C. S. 2013. Analysis of Poly (lactic-co-glycolic acid)/poly (isoprene) Polymeric Blend for Application as Biomaterial. Polímeros. 23: 579-584.

[29] Nath, S. D., Son, S., Sadiasa, A., Min, Y. K., and Lee, B. T. 2013. Preparation and Characterization of PLGA Microspheres by the Electrospraying Method for 
Delivering Simvastatin for Bone Regeneration. Int J Pharm. 443: 87-94.

[30] Félix Lanao Rosa P., Kemal S., Huanan W., Wolke Joop G. C., Jansen John A., and Leeuwenburgh Sander C. G. 2013. Accelerated Calcium Phosphate Cement Degradation Due to Incorporation of Glucono-DeltaLactone Microparticles. Tissue Eng A. 20: 378-388.
[31] Chang, H. I., and Wang, Y. 2011. Cell Responses to Surface and Architecture of Tissue Engineering Scaffolds. In: Eberli D, Editor. Regenerative Medicine and Tissue Engineering-Cells and Biomaterials, Croatia: InTech. 27: 569-588

[32] D'Souza, S., Dorati, R., and DeLuca, P. P. 2014. Effect of Hydration on Physicochemical Properties of End-capped PLGA. Adv Biomater. 1-9. 